\title{
SERUM LH IN EWES FOLLOWING SEQUENTIAL REMOVAL OF OVARIAN FOLLICLES, CORPORA LUTEA AND STROMA
}

\author{
J. F. ROGHE,* F. J. KARSGH, D. L. FOSTER \\ AND P. J. DZIUK \\ *The Agricultural Institute, Grange, Dunsany, Co. Meath, Ireland, and \\ Animal Genetics Laboratory, University of Illinois, Urbana, \\ Illinois 61801, U.S.A.
}

(Received 25th March 1974)

The ovary exerts a dominant influence on the secretion of gonadotrophins from the pituitary gland (Nalbandov, 1964). Ovariectomy of ewes caused an increase in serum LH and FSH (Arendarčik \& Maraček, 1968; Roche, Foster, Karsch \& Dziuk, 1970). The purpose of this experiment was to determine which compartments of the ovary (follicles, CL or stroma) normally maintain the basal level of $\mathrm{LH}$ in serum during the luteal phase of the oestrous cycle and throughout anoestrus (Roche, Foster, Karsch, Cook \& Dziuk, 1970; Denamur, 1972).

Twenty Grade Columbia ewes of 4 to 8 years of age were penned outdoors with 'painted' vasectomized rams. Ewes were checked twice daily for marks and the day of oestrus was designated Day 0 of the oestrous cycle. The ovaries were exposed at mid-ventral laparotomy and, according to the experimental protocol, they were either observed, removed, or X-irradiated. Ovarian X-irradiation was performed on Day 6 of the oestrous cycle to destroy follicles selectively without directly harming the remainder of the ovary (Lacassagne, Duplan, Marcovich \& Raynaud, 1962). One ovary at a time was brought to the surface, and the entire ewe was shielded with a lead drape ( $\frac{1}{8}$ in. thick, Bar Ray Products) leaving the ovary exposed through a small slit. Each ovary was irradiated individually with 1500 to $1600 \mathrm{R}$ from a Picker deep-therapy X-ray machine operated at $280 \mathrm{kV}$ and $20 \mathrm{~mA}$ with a high voltage line in copper of $1 \mathrm{~mm}$. Approximately $250 \mathrm{R} / \mathrm{min}$ were delivered through a target distance of $37.5 \mathrm{~cm}$.

The method of blood collection and of assay of $\mathrm{LH}$ used have been previously described (Roche, Foster, Karsch, Cook \& Dziuk, 1970). The lower limit of sensitivity of the radioimmunoassay was $0.2 \mathrm{ng} / \mathrm{ml}$, and all results were expressed in terms of the NIH-LH-S13 standard.

From gross observation and histological examination, no antral follicles were present in the ovaries after $\mathrm{X}$-irradiation; occasionally a primary follicle was present.

Blood was collected daily from four ewes between Days 1 and 6 of the oestrous cycle. On Day 1 , the concentration of $\mathrm{LH}$ was relatively high, presumably due to the ovulatory peak of serum LH associated with heat on Day 0 (Niswender, Roche, Foster \& Midgley, 1968) but on Days 2 to 6, the mean concentration 
of serum LH was $<1.0 \mathrm{ng} / \mathrm{ml}$ (Text-fig. 1). On Day 6, the ovaries of these four ewes and those of sixteen additional ewes were $\mathrm{X}$-irradiated. The sixteen ewes were then slaughtered in groups of two, four, seven and three on Days 11, 14, 17 and 20, respectively, and blood and CL were collected.

In X-irradiated ovaries, follicles had been destroyed by Day 11 and the CL of most ewes were still functional on Day 17 (Karsch, Noveroske, Roche, Norton \& Nalbandov, 1970). Thus, the values of $\mathrm{LH}$ between Days 11 and 17 represent values found in the absence of ovarian follicles. The level of LH in fourteen of these sixteen ewes was low (mean $<1 \mathrm{ng} / \mathrm{ml}$ ); two of the sixteen ewes which were slaughtered on Day 17 had a much higher concentration of serum LH (Text-fig. 1).

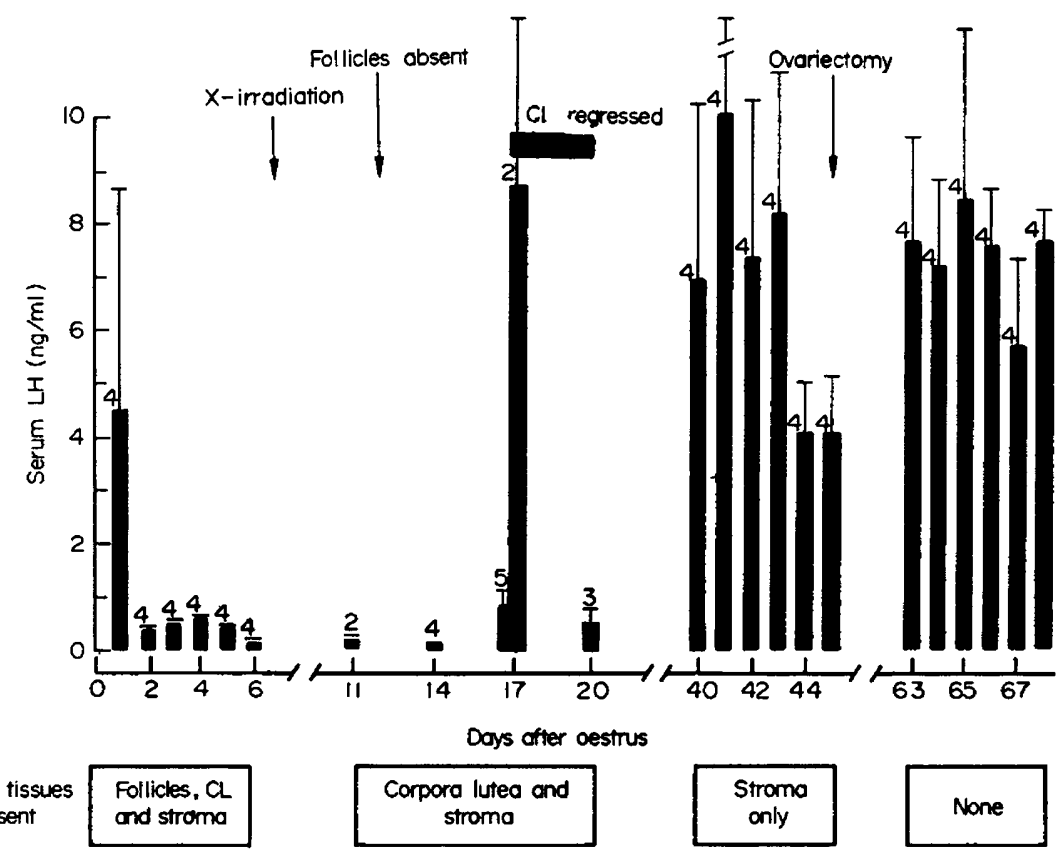

TEXT-FIG. 1. Levels of LH in serum following the sequential removal of follicles, CL and stroma from ewes after the onset of oestrus (Day 0). The figures above the columns represent the number of ewes and the vertical bars represent the S.E.M.

The original group of four ewes bled between Days 0 and 6 and $\mathrm{X}$-irradiated on Day 6 were subjected to laparotomy on Day 20. No CL or follicles were present. These ewes were then bled daily from Days 40 to 45 to obtain the level of serum LH in the absence of both follicles and CL but in the presence of ovarian stroma. The concentrations of $\mathrm{LH}$ in sera from the samples taken on Days 40 to 45 were greatly elevated (Text-fig. 1). These four ewes were ovariectomized on Day 46 and then bled again from Days 63 to 68. The levels of LH in sera after ovariectomy (Text-fig. 1) were similar to those in ewes with only ovarian stroma (Days 40 to 45 samples). This indicated that the stromal tissue alone was insufficient to inhibit release of $\mathrm{LH}$.

To study the levels of LH in sera of ewes whose ovaries contained follicles and 
stroma but not $\mathbf{C L}$, four ewes were bled for 3 days during anoestrus when CL were absent and a medium-sized follicle was present. The average serum LH concentration (Text-fig. 2) was similar to that in ewes whose ovaries contained follicles, CL and stroma (i.e. $<2 \mathrm{ng} / \mathrm{ml}$ ). Ovariectomy of these four ewes during anoestrus resulted in a dramatic increase in the level of serum LH (Text-fig. 2) as reported by Reeves, O'Donnell \& Denorscia (1972), indicating that ovaries with follicles and stroma but not CL inhibited the release of LH from the pituitary.

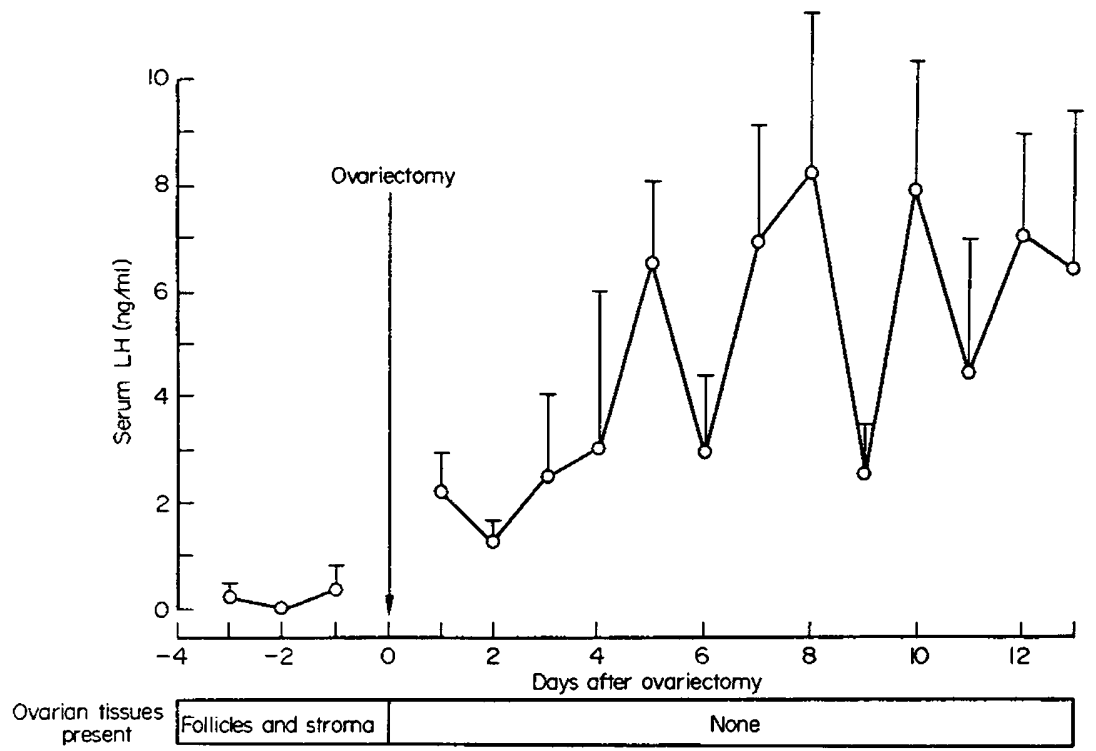

TEXT-FIG. 2. Levels of LH in the serum of four anoestrous ewes before and after ovarietomy. The vertical bars represent the S.E.M. The mean serum LH level was $0 \cdot 2 \mathrm{ng} \mathrm{LH} / \mathrm{ml}$ before, and $4.79 \mathrm{ng} \mathrm{LH} / \mathrm{ml}$ after ovariectomy.

The average concentration of $\mathrm{LH}$ in the sera of ewes between Days 1 and 6 of the oestrous cycle was low $(<1 \mathrm{ng} / \mathrm{ml}$ ), but the levels increased dramatically following ovariectomy. This indicated that the combination of follicles, GL and stroma normally inhibits release of $\mathrm{LH}$ from the pituitary of the ewe. The level of $\mathrm{LH}$ remained low $(<\mathrm{ng} / \mathrm{ml})$ in ewes whose ovaries contained either CL and stroma or follicles and stroma, but not in ewes whose ovaries contained only stromal tissue. The levels of $\mathrm{LH}$ when only ovarian stroma was present were indistinguishable from those in spayed ewes. This suggests that either progesterone from the CL or oestrogen from the follicles, alone or in combination, is sufficient to inhibit the release of $\mathrm{LH}$ from the pituitary and thus maintain the basal level of LH in serum. Ovarian stroma apparently does not inhibit the secretion of $\mathrm{LH}$.

During anoestrus, the ovaries of the ewe are inactive and generally contain only small to medium-sized follicles (Kammlade, Welch, Nalbandov \& Norton, 1952). The present study indicated that ovariectomy of ewes during anoestrus was followed by the same dramatic increase in serum LH as that occurring 
during the breeding season (Roche, Foster, Karsch \& Dziuk 1970). Therefore, the follicles of the anoestrous ovary are not quiescent but secrete a hormone, presumably an oestrogen, in sufficient quantities to inhibit the secretion of $\mathrm{LH}$.

In ewes with X-irradiated ovaries, CL had regressed by Day 20 after oestrus. This finding agrees with a previous report (Karsch et al., 1970). While the regression is slower than occurs in normal ewes (Karsch et al., 1970), it can apparently occur in the absence of ovarian follicles. If prostaglandin $F_{2 \alpha}$, which has been reported to be the luteolysin in ewes (McCracken \& co-authors, 1972), was responsible for the luteal regression in the X-irradiated ovaries, it would appear that its luteolytic effect is independent of ovarian oestrogen.

Thanks are due to Dr G. D. Niswender for supplying antiserum, Dr L. E. Reichert, Jr, for purified ovine LH and to Mr S. Jayaranan for help with ovarian X-irradiations.

\section{REFERENGES}

ARENDARČrK, J. \& MARAČEK, I. (1968) FSH and LH level in serum following bilateral ovariectomy in in sheep. Endocrinol. exp. 2, 193.

DenamuR, R. (1972) Regulation neuroendocrinienne du cycle oestrien chez les animaux domestiques. Proc. 7th Int. Congr. Anim. Reprod. E̋ A. I., Munich, 1, 20.

Kammlade, W. G., JR, Welch, J. A., Nalbandov, A. V. \& Norton, H. W. (1952) Pituitary activity of sheep in relation to the breeding season. F. Anim. Sci. 11, 646.

Karsch, F. J., Noveroske, J. W., Roche, J. F., Norton, H. W. \& Nalbandov, A. V. (1970) Maintenance of ovine corpora lutea in the absence of ovarian follicles. Endocrinology, 87, 1228.

Lagassagne, A., Duplan, J. F., Marcovich, H. \& Raynaud, A. (1962) The action of ionizing radiations on the mammalian ovary. In The Ovary, Vol. II, p. 463. Ed. S. Zuckerman. Academic Press, New York.

McGracken, J. A., Carlson, J. G., Glew, M. G., Goding, J. R., Baird, D. T., Green, K. \& Samuelsson, B. (1972) Prostaglandin $\mathrm{F}_{2 \alpha}$ identified as a luteolytic hormone in the sheep. Nature, New Biology, 238, 129.

Nalbandov, A. V. (1964) Reproductive Physiology. Freeman, San Francisco.

Niswender, G. D., Roche, J. F., Foster, D. L. \& MidGley, A. R., JR (1968) Radioimmunoassay of serum levels of luteinizing hormone during the cycle and early pregnancy in ewes. Proc. Soc. exp. Biol. Med. 129, 901 .

Reeves, J. J., O'Donnell, D. A. \& Denorscia, F. (1972) Effect of ovariectomy on serum luteinizing hormone (LH) concentrations in the anestrous ewe. F. Anim. Sci. 35, 73.

Roche, J. F., Foster, D. L., Karsch, F. J., Cook, B. \& Dziuk, P. J. (1970) Levels of luteinizing hormone in sera and pituitaries of ewes during the estrous cycle and anestrus. Endocrinology, 86, 568.

Roche, J. F., Foster, D. L., Karsch, F. J. \& Dzurk, P. J. (1970) Effect of castration and infusion of melatonin on levels of luteinizing hormone in sera and pituitaries of ewes. Endocrinology, 87, 1205. 